\title{
The Capital Structure of Business Start-Up: Is There a Pecking Order Theory or a Reversed Pecking Order?
}

\section{-Evidence from the Panel Study of Entrepreneurial Dynamics}

\author{
Hédia Fourati, Habib Affes \\ Faculty of Economics and Management, University of Sfax, Sfax, Tunisia \\ Email: hedia.fourati@yahoo.fr, habib.affes@yahoo.fr
}

Received May 12, 2013; revised June 12, 2013; accepted June 19, 2013

Copyright (C) 2013 Hédia Fourati, Habib Affes. This is an open access article distributed under the Creative Commons Attribution License, which permits unrestricted use, distribution, and reproduction in any medium, provided the original work is properly cited.

\begin{abstract}
Using the Panel Study of Entrepreneurial Dynamics, we study if the problems of asymmetry and opacity of information, asset specificity, agency problem and signaling theory predict the financial structure at inception. Thus, we conduct a study in two steps. First, by analyzing the descriptive statistics, we find that novice entrepreneurs turn first to internal sources of finance. Then, they apply to external debts and finally to equity finance. We prove then the applicability of the Pecking order theory in case of entrepreneurial firms. Second, by analyzing the role of financial theory in predicting the capital structure of entrepreneurial firms we find the following results. In fact, evidence from analyzing the role of information opacity, asset specificity and signaling theory, proves that the main source of finance is equity rather than debt. In the majority of the cases, depth interviews show from studying the financial theory an inverted pecking order. Two main reasons for this pattern can be established. First, entrepreneurs consider debt as a personal liability as it requires to be underwritten by personal guarantees. Entrepreneurs place a self-imposed limit on the extent to which they are prepared to mortgage their assets. Second, entrepreneurs deliberately seek out equity investment as a means of obtaining added value. This external equity which has been viewed as expensive is viewed as good value. A well chosen investor can add business skills and social capital in the form of commercial contacts and access to relevant networks.
\end{abstract}

Keywords: Pecking-Order Theory; Capital Structure; Asset Specificity; Signaling Theory; Moral Hazard; Credit Rationing; Information Opacity

\section{Introduction}

One of the most fundamental questions of enterprise research: "How business start-ups are financed?" In fact, theoretical principles underlying the capital structure and financing choices can be generally described in terms of static trade-off or in term of Pecking-order framework. Nevertheless, researchers have demonstrated that the Trade-off theory is not profitable for young firms, [1]. Static trade-off includes the tax benefits of leverage and bankruptcy costs, [2]. Young firms have less tax benefits which are associated with more debt use, (Day et al., 1983). The second component of the trade-off theory is the bankruptcy cost. In fact, "young firms are more failure prone than older ones" [3]. Nevertheless, bankruptcy costs are insufficient for proving the negative association between risk and leverage, [4]. Entrepreneur is more concerned with debts than its tax benefits. Thus, researchers demonstrated that the Pecking-order theory is more suitable for justifying the financial choice of new firm. This result is attributable to the importance of internal/external debts vs. internal/external equity for the entrepreneur, $[5,6]$. To the best of our knowledge little empirical validation of pecking order prediction has been previously developed for a sample of business start-up, [7]. In fact, [8] used a sample of new technology based firms; the study of [5] investigates a sample of business start-up. The latter studied the problem of information opacity, asset specificity and human capital as determinants of capital structure of business start-up. The originality of this paper is in testing in more depths how the financial theories (information opacity, agency problem, transaction costs, signaling theory and human capital) may predict the capital structure. As our knowledge we find others research doing so but for a sample of SME not for business start-up, [9]. 
By the present research, we aim to study in one hand the possible application of the Pecking order Theory and in another hand the role of financial theory in predicting the capital structure of entrepreneurial firms. The organization of this paper is as follows: Section 2 is the study of the applicability of the pecking order theory; Section 3 is a summary of the role of financial theory in explaining the capital structure, Section 4 introduces the model construction, including selection of variables, data resources, model formulation as well as the estimation method and results and Section 5 draws conclusions and results.

\section{Related Literatures}

The literature introduced two opposite frameworks relevant to the financing hierarchy of business start-ups: a standard POT, following the spirit of Myers and Majluf, (1984) and a reversed POT where external equity is preferred over external debt. Recent theoretical work has shown this pecking order is reversed where investors have superior knowledge about the commercialization process of an entrepreneur's invention, and/or add value to the entrepreneur's project, [10]. However, the empirical works testing these theories have one substantial limit, [11]. In fact, the capital structure is investigated by descriptive statistics relevant to the amount of different financing sources. Comparing the magnitude of each source, a financial hierarchy can be verified. This approach prevents us from understanding the capital structure dynamics and determinants. Therefore we maintain to contribute with a more robust, explicit and comparative testing of the pecking order theory on the one hand by investigating the descriptive statistics and on the other hand by studying the role of financial theory in justifying the financial structure of start-up activities. We aim to respond to the following question: Is there a Pecking order theory or a reversed Pecking order of the capital structure of business start-ups?

\section{The Pecking Order Theory in Case of Entrepreneurial Firm's}

In fact, the Table 1 presents the different options of fi-

Table 1. Different sources of funding, \$ value and percentage of firms.

\begin{tabular}{|c|c|c|c|c|}
\hline Means & Source of funding & $\mathbf{N}^{1}$ & $\%^{2}$ & Value $^{3}$ \\
\hline \multirow{2}{*}{ Personal savings } & By the entrepreneur & 886 & $73 \%$ & 12291.02 \\
\hline & By others owners & 330 & $27.2 \%$ & 85390.37 \\
\hline Internal equity & Of the entrepreneur & 558 & $46 \%$ & 12,686 \\
\hline \multirow{7}{*}{ Personal debt } & Others sources by others owners & 7 & $0.6 \%$ & 3241 \\
\hline & Personal debt to the new business & 68 & 5.6 & 85,796 \\
\hline & Other personal loans to the new business in the first year that must be paid back & 49 & $4 \%$ & 46,636 \\
\hline & Personal debt from relatives and family & 159 & $13.1 \%$ & 2857.49 \\
\hline & Personal debts of others owners from their family & 40 & $3.3 \%$ & 3033 \\
\hline & Personal debts of others owners from colleagues and employers & 18 & $1.5 \%$ & 369 \\
\hline & Personal debts from colleagues and employers & 57 & $4.7 \%$ & 1478.77 \\
\hline \multirow{5}{*}{ Internal debt } & Debts of the activity from the entrepreneur & 369 & $30.4 \%$ & 12296.85 \\
\hline & Debts of the activity from others owners & 149 & $12.3 \%$ & 296605.94 \\
\hline & Debts from others & 12 & $1 \%$ & 246 \\
\hline & Personal debts from relatives in the first year & 5 & $0.4 \%$ & 566 \\
\hline & Personal credit for employees who do not share the ownership of the business during the first year & 1 & $0.1 \%$ & 9 \\
\hline Total debts & 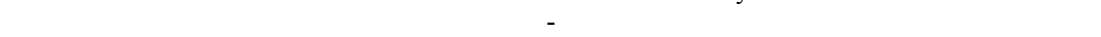 & & & 589449.77 \\
\hline \multirow[t]{9}{*}{ Total of internal finance } & - & & & 602135.77 \\
\hline & Venture capitalist & 1 & - & 203 \\
\hline & Credit card of the entrepreneur & 122 & $10 \%$ & 775.00 \\
\hline & Credit card of others owners & 28 & $2.3 \%$ & 1164.14 \\
\hline & Bank debt by the entrepreneur & 97 & $8 \%$ & 3744.29 \\
\hline & Bank debt by others owner & 43 & 3.5 & 10296.51 \\
\hline & Asset backed loan like a second mortgage or car loan by the entrepreneur & 49 & $4 \%$ & 1778.58 \\
\hline & asset backed loan like a second mortgage or car loan by others owners & 22 & 1.8 & 38980.73 \\
\hline & Leasing & 13 & $1.1 \%$ & 8212.4 \\
\hline \multirow[t]{7}{*}{ External debts } & Bank line of credit, credit to finance working capital & 13 & $1.1 \%$ & 2941.18 \\
\hline & Debt from supplier & 13 & $1.2 \%$ & 871 \\
\hline & Credit card of the activity & 17 & $1.4 \%$ & 1444 \\
\hline & Bank debt of the new activity & 11 & $0.9 \%$ & 14,250 \\
\hline & Bank loans by SBA guarantee & 24 & $0.2 \%$ & 2637 \\
\hline & Asset backed loan & 121 & $10 \%$ & 95,215 \\
\hline & Others loans & 5 & $0.4 \%$ & 2123 \\
\hline Total external debts & & & & 225023.83 \\
\hline Total & $828386 \$$ & & & \\
\hline
\end{tabular}

${ }^{\mathbf{1}}$ This is the number of companies that adopt this modality of financing; ${ }^{2}$ Is the percentage of firms whose value financing modality is greater than zero; ${ }^{3}$ This is the average value in $\$$. 
nance to entrepreneurial firms; their average value and the percentage of firms that use each modality.

Table 1 produces a set of thirty-three sources of funding that may be adopted by new entrepreneurs in the USA. $\mathbf{4 6 \%}$ of the newly created firms have some equity stake. The average of this contribution is in the order of 12,686\$. In fact, $73 \%$ of entrepreneurs contribute to financing the activity by their personal savings and its average value is about $12,291 \$$ against $27 \%$ as a contribution in personal savings by other owners whose average contribution is about $\mathbf{8 5 , 3 9 0 \$}$. Thus, the personal debt has a minimal role. In fact, one quarter of the companies adopt this type of financing. The majority of personal debt adopted by entrepreneurs is in the form of bank credit card. The average contribution of this type of funding is about $\mathbf{7 7 5} \mathbf{\$}$. $90 \%$ of entrepreneurs use some bank loans for financing new venture. Nevertheless, most personal contribution of the entrepreneur is by their personal savings. Indeed, more than half of entrepreneurial activities use this type of financing. It is mobilized through an equity stake.

Internal debt is preferred to internal equity (the contribution of business owners). Similarly, external debt is preferred rather than external equity mobilized by venture capitalists. Venture capitalists provide an average of 203\$. Indeed, only 121 new companies were able to attract the participation of investors.

Taking into account the role of insiders, the contribution of the entrepreneur is mobilized by half of the sample.

In addition, internal debt is a source of funding that should not be overlooked. The average contribution of this category of funding is by $\mathbf{3 2 6 , 0 4 8 \$}$. This funding takes the form of debt from family, friends, colleagues, former employers and the contribution of the entrepreneur as a credit for the new venture. For example, $\mathbf{4 3 \%}$ of start-ups adopt this type of financing to launch its business; its average contribution is about $\mathbf{3 0 8 , 9 0 8 \$}$. Thus, personal savings of the founder is a source of financing which is adopted by the majority of entrepreneurs. In fact, weight intervention funding by the founding entrepreneur is higher than that of other partners for all types of internal financing.

We are going now to compare the financial structure by "insiders" and "outsiders".

In fact, $\mathbf{1 2 \%}$ of the entrepreneurs adopt a financing by bank loans. This contribution is about 14,041\$. $6 \%$ of the entrepreneurs use a bank loan financing backed by an asset. This contribution is an average of 40,759\$. Indeed, the importance of bank debt with guarantee in the launch phase is quite crucial [12]. It turns out that companies with more tangible assets have less financial constraints, [13]. For instance, Leasing, lines of credit and credit providers have a relatively the lowest percentage $1 \%$ and their average values are successively: 8212\$, 2941\$ and 871\$.

Taking into account the role of indebtedness for fi- nancing new firms creation, we find that this type of financing choice is adopted with low percentages: $\mathbf{1 \%}$. This debt comes from bank loans, the government debt and bank loans with $\mathrm{SBA}^{1}$ guarantee.

In fact, internal debt is a source of financing which is very considerable than external debt. It has a double in value.

One point to admit in entrepreneurial finance is that the entrepreneur lacks access to formal capital market.

The table above reflects the terms of the applicability of entrepreneurial finance in terms of financial choices. The newly created firms have an average capital of about $\mathbf{8 2 8 , 3 8 6 \$}$. Half of it comes from internal debt and the quarter from external debt.

The majority of funds come from external bank loans backed by asset and from credit cards. If we relate the total credit card of the entrepreneur to the credit card company, we find that it is the seventh. This result confirms that the majority of funding comes from the entrepreneur.

On this way, we can suggest some "Pecking Order" which describes the capital structure of business start-up. If we treat the equity contribution and personal debt as internal funds, we find that many companies consider their internal funds, fewer companies relate to debt and less to venture capitalists. This confirms the message which is transmitted by Myers and Majluf, (1984) about the "Pecking Order". Some authors introduced the need to revise the POT, since they found evidence that both retained earnings and external equity are quite unusual means of financing for new firms; debt also seems to be disregarded compared to internal funds [14]. Literature has recently introduced a revised version of the POT, where external equity is preferred over external debt in the case of innovative firms [15]. According to his study the pecking order theory in the case of innovative firms is reversed as follows: 1) Insider Capital, informal private equity and easy-term financing (seed); 2) Venture capital financing (start-up); 3) Self financing, banks and or business credit (early growth); 4) Direct issue of bonds and public equity (sustained growth).

Is there a Pecking order theory or a reversed Pecking order if we consider a more dynamic approach that analyzes the role of information opacity, asset specificity and signaling theory in predicting the capital structure of start-up?

\section{The Financial Theory as a Determinant of the Capital Structure of Business Start-Up}

We study the role of information opacity, agency prob-

\footnotetext{
${ }^{1}$ The Small Business Administration (SBA) is a United States government agency that provides support to entrepreneurs and small businesses. SBA loans are made through banks, credit unions and other lenders who partner with the SBA. The SBA provides a government-backed guarantee on part of the loan, Wikipédia, 2012.
} 
lems, signaling theory and transaction costs in defining the existence of a POT or a reversed POT for business start-up.

\subsection{Information Opacity and Capital Structure of Entrepreneurial Firms}

Previous studies demonstrated that new firms have no historical and no reputational effects. Thus, business is informationally opaque. This informational problem makes the external financing not available at start-up phase, [16]. Under this problem, a Pecking order will take place. Firstly, personal savings, secondly short-term debt, then long-term debt, and ultimately and the least preferred is the role of external investors, [17]. Given the difficulty in obtaining external financing, entrepreneurs rely heavily on internal funds, [18]. Under the condition of information opacity, after internal funds, the firm must resort to bank borrowings then to equity contributions. Indeed, a relationship of debt is based on "soft" information generated by the banking experience with the lender and by a continuous contact bank-owner by providing some financial services, [19], p. 645. Some studies have demonstrated the importance of the relationship of debt in granting loans to small businesses, Hanley and Crook, (2005). Due to this informational problem, internal financing is the primary source of funding followed by external debt and ultimately a limited amount of external equity. The following hypotheses regarding the problem of information opacity are proposed:

H1: information opacity is positively correlated with the probability of using internal funds in financing new venture creation;

H2: Information opacity is negatively associated with the probability of using bank debts in financing new venture;

H3: Information opacity is negatively associated with the probability of financing the new venture by external equity;

Nevertheless, information problem may create some agency problems. In the following section, we analyze the role of moral hazard problem and credit rationing in justifying some financial choice of the entrepreneurial firms.

\subsection{Agency Problems and Capital Structure of the Entrepreneurial Firms}

The provision of loan by investor to the entrepreneur will create an agency relationship between the entrepreneur (the agent) and the investor, who is the principal, [20]. Agency problems are more developed in small entrepreneurial firms than their counterparts large firms. In fact, collecting information by financial intermediary is rare and expensive, [21]. The sharing in capital with the ven- ture capitalist involves establishing a cooperative relationship between the investor and the entrepreneur, [22].

*Moral hazard and capital structure of the entrepreneurial firms

Due to the inability to write complete contracts specifying the benefits right under any liquidation act, the entrepreneur has interest to expropriate funds after signing the contract with the bank, Huyghebaert and Van De Gucht, (2007). The moral hazard problem leads therefore to a first incentive to undertake riskier projects and incentives of underinvestment in projects with positive net present value.

*Credit rationing and capital structure of the entrepreneurial firms

There are two theoretical models emphasizing credit rationing, [23]. Indeed, these models are those of (Stieglitz and Weiss, 1981) and [24]. Due to the problem of credit rationing, loan applicants are generally the firms with good quality. For those who come to borrow, the bank increases the value of the debt and/or increase the maturity of the credit. Credit rationing affects only the decision of bank financing, and will have no effect on debt, Huyghebaert and Van De Gucht, (2007). This discussion leads to the following hypothesis:

H4: agency problems must be negatively associated with the probability of using bank debt in financing new venture.

\subsection{Asset Specificity and Capital Structure of the Entrepreneurial Firms}

The theory of transaction costs defined by Williamson, (1988) implies that the specific assets generate quasirents for business. The asset specificity is a source of competitive advantage in the market, [25]. Assets of an entrepreneurial project may be specific to it and the optimal financial contract is one that minimizes transaction costs. The asset specificity for start-ups gives rise to two main problems. The first is related to the lowest net asset value. The second is related to the "hold-up problem" due to the specific human capital which gives rise to the opportunism problem. In business start-up, the entrepreneur will contribute not only by his managerial skills but also contribute with his financial capital, his knowledge and his human capital, [26]. The relative importance of the intangible assets does not always allow banks to have guarantees, [27].

Such assets have high transaction-costs and do not allow bankers to hedge against the risk of bankruptcy. Thus external investors and especially lenders may be reluctant to finance such projects. New venture that has more specific assets should primarily be financed through equity and secondly through a public offering and finally by external debt, Huyghebaert and Van De Gucht, (2007). One proposed solution to this problem of "hold-up" is to 
grant control rights to the entity that has specific resources, [28]. Based on our review of the role of asset specificity in new venture financing, we propose to test the following hypothesis:

H5: Asset specificity must be negatively correlated with the probability of using external debts;

H6: Asset specificity must be positively associated with the probability of using internal fund for new venture financing;

H7: asset specificity must be positively associated with the probability of using external equity for new venture financing.

\subsection{The Signaling Theory and the Capital Structure of Entrepreneurial Firms}

Following the literature the contribution of the entrepreneur in the project serves as a signal of its quality, [29]. In fact, the capital of the entrepreneur is engaged as a credit guarantees and has a signal effect, [30]. Indeed, the willingness of the lender to fund new projects is positively related to the personal guarantee of the entrepreneur especially regarding the personal funds that are invested, [31]. The size of the ratio of debt to guarantee exceeds the unity for $85 \%$ of small businesses in the UK, [32]. In fact, the underlying asset has different roles for the financial institution. Warranty can cover the contractor to overcome the problem of moral hazard, [33]. It is a signal to the bank stating that the contractor perceives that his project will win. Similarly, the guarantee constitutes a solution of the problem of information asymmetry and reduces the problem of credit rationing, [34]. The underlying asset allows the renegotiation of the contract in case of financial distress, [35]. Regarding the role of the signaling theory in explaining the financial decision of entrepreneur we aim to test the following research hypothesis:

H8: An increase in equity contribution of the entrepreneur and the other owners is a signal to increase the probability of financing by bank debt;

H9: An increase in the entrepreneur's and other owners' personal guarantees of the business are a signal to increase the probability of financing by bank deb.

\subsection{Characteristics of the Activity and the Capital Structure of Entrepreneurial Firms}

\section{* The role of size}

Previous studies explained the existence of a positive correlation between long-term debt and size. In fact, smaller firms employ less long-term debt due to scale effects. This positive relationship may also be accounted for by collateral effects, as the natural logarithm of total assets is commonly employed as a proxy variable for size. This finding is consistent with the view that smaller firms are heavily reliant on short-term debt. Thus firms are unwilling or unable to use long-term debt because of the relatively higher transaction costs, Mac an Bhaird, (2010).

*The legal form of organization

The legal form of the organization provides a specific form of financing. It is a signal that indicates credibility and formality of operations and ensures future growth as noted by Cassar, (2004). There is, then, a positive correlation between debt and organization in incorporation, [36]. However, the legal organization ensures more bank debt. Under this discussion the following research hypothesis are proposed:

H10: An increase in the size of activity reduces the probability of financing the entrepreneurial projects by debts;

H11: The legal form of organization in "incorporation" is increase the probability of financing the entrepreneurial project by external debt and bank debt.

\subsection{The Entrepreneur's Attributes and the Capital Structure of the Entrepreneurial Firms}

The personal characteristics include gender, education [37] and experience.

H12: The individual characteristics of an entrepreneur increase the probability of financing new venture by debts.

\section{Data}

Our analysis uses the detailed data in the Panel Study of Entrepreneurial Dynamics (PSED). The description of the background and the sampling methodology are presented by, [38]. The PSED is a longitudinal database selecting the period 2005-2010. PSED was started in 2005 with the selection of a cohort of 1214 nascent entrepreneurs chosen from a representative sample of 31,845 adults. In the first year, a follow-up interview was completed with 1214 entrepreneurs $(80 \%$ of the original cohort): $87 \%$ of the interviewed persons are "novice" entrepreneur; $60 \%$ of them have accepted to participate to a second interview after one year.

\subsection{Model and Measure of Variables}

* Model

In our model the dependent variable is dichotomous (i.e., whether or not an individual use the mean of finance in internal or external funds). Accordingly, we use the logistic regression methodology to estimate the coefficients. The generalized form for the response probabilities for the model is given in the following equation:

$$
\begin{aligned}
& P\left(\text { financing }_{i}\right) \\
& =\alpha+\theta_{1} \text { inf opacity }+\theta_{2} \text { agency }+\theta_{3} \text { asset specificity } \\
& +\theta_{4} \text { signaling }+\theta_{5} \text { entrepreneu attributes }+\theta_{6} \text { Activity }+\varepsilon
\end{aligned}
$$


where:

$\checkmark$ financing, is a dichotomous variable that measures if the entrepreneur adopt one of the modalities of financing in 1) the owner resource, 2) internal finance, 3) external finance, 4) bank finance and 5) the outside equity).

$\checkmark$ "Information opacity": Is a vector that explain the existence or not of certain information opacity.

$\checkmark$ Agency problem: Is a vector that explains the existence or not of an agency problem in moral hazard and credit rationing.

$\checkmark$ Asset specificity: Is a vector that explains the existence or not of an asset specificity.

$\checkmark$ Signaling: Explains the owner's contribution to col- lateralize and/or to finance the entrepreneurial project.

\section{*Measure of variables}

Table 2 explains the different items of the dependent and the independent variables. Information opacity is measured by a home based activity, if the entrepreneur is a serial one. Asset specificity is measured by the entrepreneurial experience, the industrial experience, the value of tangible assets and the existence of an intellectual property. Agency problems consist in credit rationing and moral hazard. The signaling theory is measured by the value of the entrepreneur's asset and his contribution to finance the activity in equity finance. Control variables are in the entrepreneur's attributes and the characteristics of activity.

Table 2. Measure of variables of the model.

\begin{tabular}{|c|c|c|}
\hline Variables & Labels & Measures \\
\hline \multicolumn{3}{|l|}{ Dependent variables } \\
\hline Internal equity & PCINTERNE & $\begin{array}{l}\text { Dichotomous variable coded " } 1 \text { " if the share of capital retained by } \\
\text { the entrepreneur exceeds or equal } 50 \% \text {. }\end{array}$ \\
\hline Internal debts & DETEINTERNE & $\begin{array}{l}\text { Dichotomous variable coded " } 1 \text { " if the entrepreneur use some debts from family, } \\
\text { friends and others personal resources. }\end{array}$ \\
\hline External debts & DETEXTERNE & $\begin{array}{l}\text { Dichotomous variable coded " } 1 \text { " if the entrepreneur have some debts from banks, } \\
\text { credit cards, suppliers and others external debts. }\end{array}$ \\
\hline Bank debts & CREDIBANC & $\begin{array}{l}\text { Dichotomous variable coded " } 1 \text { " if the entrepreneur uses some bank debts } \\
\text { for financing the new venture. }\end{array}$ \\
\hline $\begin{array}{l}\text { Bank debt } \\
\text { with guaranty }\end{array}$ & CREDIBANGAR & Dichotomous variable coded " 1 " if the entrepreneur uses some secured bank debts. \\
\hline External equity & PCEXTERNE & Dichotomous variable coded "1" if the entrepreneur uses some external equity. \\
\hline \multicolumn{3}{|l|}{ Independent variables } \\
\hline \multicolumn{3}{|r|}{ INFORMATION OPACITY } \\
\hline Home based & RESIDENCE & Dichotomous variable coded " 1 " if the venture is based in the home of the founder. \\
\hline Serial & SERIAL & The total numbers of the activities which are started by the owners of this venture. \\
\hline \multicolumn{3}{|r|}{ ASSET SPECIFICITY } \\
\hline $\begin{array}{l}\text { Entrepreneurial } \\
\text { expérience }\end{array}$ & EXPERIENCE_ENTREPREN & Number of years of the entrepreneurial experience in the same industry. \\
\hline Industrial experience & EXPERIENCEINDUS & Number of years of industrial experience. \\
\hline Tangible & LOG-TANG & $\begin{array}{l}\text { Value of cash available to the contractor which can be used as a collateral } \\
\text { for obtaining credit (value of physical properties of the contractor machinery, } \\
\text { construction). }\end{array}$ \\
\hline Intellectual property & PREOPRIETE-INTELLECTUELLE & $\begin{array}{l}\text { Dichotomous variable coded " } 1 \text { " if the entrepreneur has some intellectual property, } \\
\text { (patents, copyrights, and trademarks). }\end{array}$ \\
\hline \multicolumn{3}{|r|}{ AGENCY PROBLEMS } \\
\hline Moral hazard & RISQUMORAL & $\begin{array}{l}\text { Dichotomous variable coded " } 1 \text { " if the entrepreneur responds "no" to the following } \\
\text { question: "Are all funds deposited in a bank account in the name of the company?" }\end{array}$ \\
\hline Credit rationning & RATIONNEMENT & The percent of new venture which starts without looking for bank debts. \\
\hline \multicolumn{3}{|r|}{ SIGNALING THEORY } \\
\hline Personal equity & LOG-PARTICIP & Value of personal contribution to the new venture. \\
\hline Tangible & LOG-TANG & Value of tangible assets. \\
\hline \multicolumn{3}{|c|}{ ENTREPRENEURIAL ATTRIBUTES } \\
\hline Age & AGE & Age of the principal founder. \\
\hline Gender & GENRE & Dichotomous variable coded " 1 " if the entrepreneur is a man. \\
\hline Education & $\mathrm{BAC}$ & Dichotomous variable coded " 1 " if the entrepreneur has a level education. \\
\hline \multicolumn{3}{|c|}{ VENTURE CARACTERISTICS } \\
\hline Legal form & INCORPORATION & $\begin{array}{l}\text { Dichotomous variable coded " } 1 \text { " if the startup is a limited liability company, } \\
\text { a subchapter S-corporation, a C-corporation, a general partnership, or a } \\
\text { limited partnership company. }\end{array}$ \\
\hline Size & TAILLE & Number of employees in the start-up year. \\
\hline
\end{tabular}




\subsection{The Logistic Regression and the Results}

The econometric estimation of the logistic regression is presented in Table 3 and reveals the following results for each financial problem. Since most firms are financed primarily by only one type of finance, we use discrete variables (for example, the binary 0,1$)^{2}$, when describing the financial structure for each firm. For our main assessment of the PSED in the financial structure, we consider the four-way financial sources: internal equity, internal debt, external equity, and external debt, and then the six-way decomposition that focuses on the types of external debt.

From Table 3 we find that in term of information opacity, serial entrepreneurs have some reputation. New activities, that are home-based and installed by a "habitual" entrepreneur, are more exposed to problems of information opacity. For these activities, internal resources dominate the financial structure and then external debt and little equity finance. In fact, information opacity for business start-up prevents any source of external financing in the form of debt or equity, [39].

Taking into account the variables that measure the information opacity, the activities installed in own homes have the most information opacity. They are more likely to be financed by equity contribution. These entrepreneurs have less than $38 \%$ chance of having a bank debt and less than $30 \%$ chance of having external equity in their capital structure. Nevertheless there is a positive correlation with internal equity. The serial entrepreneur is more likely to finance the new venture activity by internal and external equity due to the availability of information of the owner. We show a positive correlation between a serial entrepreneur and the probability of using internal debt. The serial entrepreneur does not attract the investors in our sample. In fact, they have $68 \%$ less chance of having some external equity. With regard to the availability of information, they are more likely to have an external debt.

Table 3. Logistic regression for determinants of capital structure of business start-up.

\begin{tabular}{|c|c|c|c|c|c|c|}
\hline & $\begin{array}{l}\text { Internal equity } \\
\text { (Model 1) }\end{array}$ & $\begin{array}{l}\text { Internal debt } \\
\text { (Model 2) }\end{array}$ & $\begin{array}{l}\text { External debt } \\
\text { (Model 3) }\end{array}$ & $\begin{array}{l}\text { Bank debt } \\
\text { (Model 4) }\end{array}$ & $\begin{array}{l}\text { Secured bank loan } \\
\text { (Model 5) }\end{array}$ & $\begin{array}{c}\text { External equity } \\
\text { (Model 6) }\end{array}$ \\
\hline \multicolumn{7}{|c|}{ INFORMATION OPACITY } \\
\hline Home based activity & 0.041 & $-0.34^{*}$ & -0.317 & $-0.386^{*}$ & -0.22 & -0.28 \\
\hline Serial & -0.14 & 0.018 & 0.158 & -0.067 & -0.10 & -0.68 \\
\hline \multicolumn{7}{|c|}{ ASSET SPECIFICITY } \\
\hline $\begin{array}{l}\text { Entrepreneurial } \\
\text { experience }\end{array}$ & -0.025 & 0.937 & -0.015 & 0.227 & 0.282 & 0.337 \\
\hline Industrial experience & 0.001 & 0.0034 & -0.0049 & -0.011 & 0.012 & -0.013 \\
\hline Log (tangible asset) & 0.012 & $0.1500^{* * *}$ & $0.242^{* * *}$ & $0.144^{* * *}$ & 0.023 & 0.139 \\
\hline Intellectual property & -0.175 & 0.210 & -0.104 & 0.016 & 0.343 & -0.217 \\
\hline \multicolumn{7}{|c|}{ AGENCY PROBLEMS } \\
\hline Moral hazard & & & $-0.499^{* * *}$ & $-0.91^{* * *}$ & 0.19 & \\
\hline Credit rationning & & & 0.174 & $-0.44^{* * *}$ & 1.28 & \\
\hline \multicolumn{7}{|c|}{ ENTREPRENEUR ATTRIBUTES } \\
\hline Log (owner equity) & 0.009 & $-0.059^{* * *}$ & 0.020 & $0.069^{* * *}$ & -0.0007 & 0.012 \\
\hline Age & -0.007 & $-0.015^{* * *}$ & -0.007 & -0.005 & -0.013 & -0.01 \\
\hline Gender & -0.117 & 0.019 & $0.335^{*}$ & -0.234 & 0.06 & -0.468 \\
\hline Éducation & $0.532^{* * *}$ & -0.212 & 0.19 & -0.049 & 0.208 & -0.639 \\
\hline \multicolumn{7}{|c|}{ VENTURE CARACTERISTICS } \\
\hline Size & -0.003 & 0.003 & -0.0002 & -0.006 & -0.03 & -0.047 \\
\hline Incorporation & $0.766^{* * *}$ & -0.020 & -0.102 & $0.356^{* *}$ & -0.47 & $1.32^{* * *}$ \\
\hline \multirow[t]{2}{*}{$\mathrm{C}$} & $-0.596^{*}$ & 0.273 & 1.192 & $3.138^{* * *}$ & $-3.702^{*}$ & $-4.95^{* *}$ \\
\hline & $\begin{array}{c}\text { McFadden } \\
\text { R-squared }=4 \%\end{array}$ & $\begin{array}{c}\text { McFadden } \mathrm{R} \\
\text { squared }=3.3 \%\end{array}$ & $\begin{array}{c}\text { McFadden } \\
\text { R-squared }=7 \%\end{array}$ & $\begin{array}{c}\text { McFadden } \\
\text { R-squared }=12.5 \%\end{array}$ & $\begin{array}{c}\text { McFadden } \\
\text { R-squared }=2 \%\end{array}$ & $\begin{array}{c}\text { McFadden } \\
\text { R-squared }=9 \%\end{array}$ \\
\hline
\end{tabular}

${ }^{2}$ Empirical work on established firms often uses the share of different types of financing instead of the 0-1 binary choice. However, for the startup financial data, the 0-1 choice variable is superior because some of the shares are small while others are at such extremes that there would not be a normal distribution for the share variable. 
Taking into account the extent of asset specificity, an increase in asset tangibility increases the probability of having some external debt and bank debt in its financial structure. Indeed, the tangible assets are important in the eyes of creditors. The Pecking-order theory also provides the same conclusions. Indeed, a firm having more tangible assets will be less sensitive to asymmetry of information. Tangible assets are less exposed to the problem of information asymmetry and lose, in case of liquidation, less value than the intangible assets.

Predictions based on the information opacity are classified, based on the characteristics of assets for the majority of new start-ups. For this type of business, the entrepreneur does not only have managerial expertise of the business but also produces a certain human and financial capital. This type of specific human assets cannot be transferred to alternative uses due to the problem of information opacity. As noted by Sanyal and L. Mann, (2010). The activity that has the most specific asset is primarily financed by the entrepreneur's own resources and through his participation in external capital and lastly by external debt.

Other activities acquired by the entrepreneur, may be used as collateral for financing new activities. The value of the intellectual property is less certain and brings low net asset value. We believe that a start-up with high human capital is primarily funded by internal resources and specifically by internal equity. In fact, many tangible assets increase the probability of having some internal debt by $15 \%$, and increase the probability of having a bank debt by $14 \%$. Nevertheless, increasing the probability of having some intellectual property reduces the probability of having an external debt by $10 \%$. The intellectual property reduces the probability of being financed by external funding sources. It decreases the probability of financing by bank debt.

High industrial experience (as a component of specific human capital) increases the probability of using the internal equity in financing venture activities. This effect is negative and insignificant for using external debt. The influence of industry knowledge increases the secured bank loan. Nevertheless, an increase in the knowledge of the activity mobilized by the entrepreneurial experience decreases the probability of having a debt in its external structure. This negative correlation between the entrepreneurial experience and external debt can be attributed to a loser entrepreneurial experience. The latter generates negative information about the reputational capital of the entrepreneur.

Nevertheless, it appears that the past entrepreneurial experience helps to attract the external investors.

In term of agency problem, credit rationing is negatively associated with bank debt. We notice that an increase in credit rationing decreases the use of bank debt by $44 \%$. We find also the existence of a positive correlation between credit rationing and bank loans. This result confirms those of Huyghebaert and Van De Gucht, (2007). The latter showed that bank increases the maturity of the debt when credit rationing occurs to reduce the problem of adverse selection. Moral hazard is negatively associated with external debt and bank debt. The existence of moral hazard problem reduces the use of external debt by $50 \%$ and the use of bank debt by $93 \%$.

The owner's characteristics are a determinant of the capital structure and the financial characteristics of the new activities. Age, education and gender produce a signal on the quality of the human capital. Better human capital is associated with a viable business. Therefore access to debt as noted by Storey, (1994) is more important for this type of business. An increase in equity by the owner is a signal to outsiders by providing an increase in external debt, especially bank debt. This increase is in order of $7 \%$. Taking into account the variable log-tangible as a signal for personal guarantees, the latter is positively associated with bank loans which are secured or unsecured. The newly founded activities by older entrepreneur are less financed by internal, external and bank debt. Many educated entrepreneurs are $20 \%$ more likely to be funded by bank debt and secured external debt. Contrary to the results of Sanyal and L. Mann, they are $50 \%$ more likely to be financed by internal or external equity contributions. This is associated with the condition that they have sufficient financial knowledge to be aware of the sources of bank financing and government, [40]. Venture activities founded by men are $35 \%$ more likely to be financed by external debt.

Characteristics of the activity are quite crucial to define the financial structure of the business. Banks perceive corporation serve as a signal that describes the credibility and indicates the future growth opportunities. For example there is a positive correlation between debt and the legal form. It suggests that it leads to more bank debt. The legal form is positively and significantly associated with bank loan. Indeed, the legal organization increased $36 \%$ chance of using bank debt. It constitutes a signal and attracts the external investors. It increases the probability of using external finance and by $76 \%$ the probability of using internal funds.

Taking into account the three funding scenarios flow, external debt and equity contribution to various external and financial problems of opacity information, asset specificity in agency problems and the role of signaling theory, we test the possible existence of a Pecking-order or a reversed Pecking order for justifying the financial structure of new entrepreneurial projects. We take into consideration the sign of association and the existence of a more or less elastic coefficient. Taking into account the problem of opacity information, the entrepreneur has 
more probability of being financed by personal saving, then by external equity and less chance of being financed by external debt. Indeed in term of opacity of information, we retain reversed version of the Pecking-Order. And we retain the following classification: internal funds, external equity and external debt. In terms of asset specificity, from all items, we also prove the existence of a reversed Pecking-order. Taking into account the role of signaling theory, in term of personal contribution to the venture activity and the role of tangible assets, external debts are more preferred to external equity for financing new venture creations and we prove the Pecking order theory.

\section{Conclusion}

Our study is conducted on the PSED database. We are interested in studying the decisive weight of the financial problems in information opacity, asset specificity, agency problems and signaling theory in the decision of the capital structure of the new entrepreneurial projects. From a logistic regression of binary variables that defined the sixth funding scenarios of finance, we have drawn the following conclusions. New entrepreneurial activities are more likely to have some external debt in their capital structures if they have more tangible assets that serve as collateral and if they have a legal form in incorporation. Due to the lowest value of human capital, the entrepreneurial activities in more human capital are less likely to have some external debt and more likely to be financed by internal finance. Home based activities are more likely to be financed by internal equity contributions, less by external debt and attracting less outside investors. More educated entrepreneurs contract more external debt and attract more investors. In fact, external debts bring some transaction costs. Then we studied the applicability of the POT in a context of entrepreneurial firms. We conduct two different studies. The first study is interested in some descriptive statistics of different means of finance. Then, we conclude the applicability of Pecking order theory in defining the capital structure of entrepreneurial firms. The second study is more analytic and parts from studying the role of financial theory in defining the capital structure of entrepreneurial firms. Thus, we conclude from the logistic regression the existence of a reversed Pecking order defining the capital structure of business startup except of signaling theory. The introduction of external equity into a start-up business can be seen by an owner as a dilution of control, [41]. Our results correspond to a response to the critics of Cassar, (2004) the studies of the capital structure of the entrepreneurial projects. The first method has the limit of time of using the different modalities of finance. In fact, some methods of financing are used by entrepreneur. Nevertheless, others modalities are incurred in the name of the business and after one year of the inception. Then, we explain this result by the problem of responses bias for some means of finance and especially in terms of the role of the external equity. In this paper, the sample of entrepreneurs has the limit of collecting external equity and non responses bias. This limit does not allow us treating the entire roles and issues associated with the Pecking order theory. The study conducted on the same sample leads to conclude that novice and more rich American entrepreneurs face more financial constraints, [42]. It would, therefore, be useful to chart the experience of entrepreneurs who face financial constraints. In their search for finance did they follow the sequence suggested by either the $\mathrm{POH}$ or of the reversed pecking order?

\section{REFERENCES}

[1] C. Mac an Bhaird, "The Modigliani-Miller Proposition after Fifty Years and Its Relation to Entrepreneurial Finance," Strategic Change, Vol. 19, No. 1-2, 2010, pp. 928. http://dx.doi.org/10.1002/jsc. 855

[2] S. C. Myers and N. Majluf, "Corporate Financing and Investment Decisions When Firms Have Information That Investors Do Not Have," Journal of Financial Economics, Vol. 13, No. 2, 1984, pp. 187-221. http://dx.doi.org/10.1016/0304-405X(84)90023-0

[3] R. Cressy, "Why Do Most Firms Die Young?" Small Business Economics, Vol. 26, No. 2, 2006, pp. 103-116. http://dx.doi.org/10.1007/s11187-004-7813-9

[4] P. Poutziouris and F. Chittenden and N. Michaelas, "The Financial Development of Smaller Private and Public (SMEs)," Working Paper 378, Manchester Business School, Manchester, 1999.

[5] P. Sanyal and L. M. Catherine, "The Financial Structure of Startup Firms: The Role of Assets, Information, and Entrepreneur Characteristics," Federal Reserve Bank of Boston, Working Paper 10-17, 2010.

[6] J. Rédis, "Finance Entrepreneuriale le Créateur d'Entreprise et les Investisseurs en Capital," Préface de Hughes Franc, Edition de Boek, 2009.

[7] S. Paul and G. Whittam and J. B. Johnston, "The Operation of the Informal Venture Capital Market in Scotland," Venture Capital, Vol. 5, No. 4, 2003, pp. 313-335. http://dx.doi.org/10.1080/1369106032000141931

[8] L. Cassia and T. Minola, "Pecking Order Theory Extesion and the Role of Human Capital in New Technology Based Firms. Evidence from the Kauffman Firm Survey," Paper Presented at the European Institute for Advanced Studies in Management (EIASM) RENT XXIV-Research in Entrepreneurship and Small Business, Maastricht, 1819 November 2010.

[9] A. Newan and S. Gunessee and B. Hilton, "Applicability of Financial Theories of Capital Structure to the Chinese Cultural Context: A Study of Private Owned SMEs'," International Small Business Journal, Vol. 27, 2012, pp. 470-495.

[10] M. Garmaise, "Informed Investors and the Financing of 
Entrepreneurial Projects," University of Chicago, Working Paper, 2001.

[11] G. Cassar, "The Financing of Business Start-Up," Journal of Business Venturing, Vol. 19, No. 2, 2004, pp. 261-283. http://dx.doi.org/10.1016/S0883-9026(03)00029-6

[12] A. Hanley and J. Crook, "The Role of Private Knowledge in Reducing the Information Wedge: A Research Note," Journal of Business Finance \& Accounting, Vol. 32, No. 1-2, 2005, pp. 415-433. http://dx.doi.org/10.1111/j.0306-686X.2005.00599.x

[13] M. Campello and R. J. Graham and R. C. Harvey, "The Real Effects of Financial Constraints: Evidence from a Financial Crisis," Journal of Financial Economics, Vol. 97, No. 3, 2008, pp. 470-487.

[14] A. Atherton, "Rational Actors, Knowledgeable Agents: Extending Pecking Order Considerations of New Venture Financing to Incorporate Founder Experience, Knowledge and Networks," International Small Business Journal, Vol. 27, No. 4, 2009, pp. 470-495.

http://dx.doi.org/10.1177/0266242609334969

[15] L. Sau, "New Pecking Order Financing for Innovative Firms: An Overwiew," Working Paper, Department of Economics, Università di Torino, 2007.

[16] A. Paulson and R. Townsend, "Entrepreneurship and Financial Constraints in Thailand," Journal of Corporate Finance, Vol. 10, No. 2, 2004, pp. 229-262. http://dx.doi.org/10.1016/S0929-1199(03)00056-7

[17] A. D. Cosh and A. Hughes, "Size, Financial Structure and Profitability: UK Companies in the 1980S'," In: A. Hughes and D. Storey, Eds., Finance and the Small Firm, Routledge, London, 1994.

[18] N. Huyghebaert and L. M. Van de Gucht, "The Determinants of Financial Structure: New Insights from Business Start-Ups," European Financial Management, Vol. 13, No. 1, 2007, pp. 101-133. http://dx.doi.org/10.1111/j.1468-036X.2006.00287.x

[19] A. N. Berger and G. F. Udell, "Small Business and Debt Finance," International Handbook Series on Entrepreneurship, Vol. 1, 1998, pp. 299-328.

[20] M. Cherif, “Asymétrie d'Information et Financement des PME Innovantes par le Capital Risque," Revue d'Economie Financière, Vol. 54, No. 54, 1999, pp. 163-178.

[21] T. Baas and M. Schrooten, "Relationship Banking and SMEs: A Theoretical Analysis," Small Business Economics, Vol. 27, No. 2-3, 2006, pp. 127-137. http://dx.doi.org/10.1007/s11187-006-0018-7

[22] M. Falconer, G. Reid and N. Terry, "Post Investment Demand for Accounting Information by Venture Capitalist," Managerial Finance, Vol. 20, 1994, pp. 186-196.

[23] S. Parker, "The Economics of Entrepreneurship: What We Know and What We Don't Know," Foundations and Trends, in Entrepreneurship, Vol. 1, No. 1, 2005, pp. 154. http://dx.doi.org/10.1561/0300000001

[24] O. E. Williamson, "Corporate Finance and Corporate Governance," Journal of Finance, Vol. 43, No. 3, 1988, pp. 567-591. http://dx.doi.org/10.1111/j.1540-6261.1988.tb04592.x

[25] R. D. Ireland and M. A. Hitt and D. G. Sirmon, "A Model of Strategic Entrepreneurship: The Construct and Its Dimensions," Journal of Management, Vol. 29, No. 6, 2003, pp. 963-989.

[26] D. B. Audretsch and E. E. Lehmann and L. A. Plummer, "Agency and Governance in Strategic Entrepreneurship," Entrepreneurship Theory and Practice, Vol. 33, No. 1, 2009, pp. 150-166.

[27] J. Jacquin, "Les Jeunes Entreprises Innovantes: Une Priorité pour la Croissance," Rapport du Commissariat Général au Plan, La Documentation Française, 2003.

[28] O. Hart and J. A. Moore, "A Theory of Debt Based on the Inalienability of Human Capital," The Quarterly Journal of Economics, Vol. 109, No. 4, 1995, pp. 841-879. http://dx.doi.org/10.2307/2118350

[29] H. Leland and D. Pyle, "Informational Asymmetries, Financial Structure, and Financial Intermediation," The Journal of Finance, Vol. 32, No. 2, 1977, pp. 371-387. http://dx.doi.org/10.2307/2326770

[30] A. W. Boot and A. V. Thakor and G. F. Udell, "Secured Lending and Default Risk: Equilibrium Analysis, Policy Implications and Empirical Results," Economic Journal, Vol. 101, No. 406, 1991, pp. 458-472.

[31] B. F. Blumberg and W. A. Letterie, "Business Starters and Credit Rationing," Small Business Economics, Vol. 30, No. 2, 2008, pp. 187-200.

http://dx.doi.org/10.1007/s11187-006-9030-1

[32] J. Black and D. De Meza and D. Jeffreys, "House Prices, the Supply of Collateral and the Enterprise Economy," The Economic Journal, Vol. 106, No. 434, 1996, pp. 6075. http://dx.doi.org/10.2307/2234931

[33] J. Bartholdy and C. Mateus, "Financing of SME's: An Asset Side Story," Société Universitaire Européenne de Recherches Financiéres, Palais du Luxembourg, Paris, 2008.

[34] D. J. Storey, "Understanding the Small Business Sector," Routledge, New York, 1994.

[35] G. Gorton and J. Kahn, "The Design of Bank Loan Contracts," The Review of Financial Studies, Vol. 13, No. 2, 2000, pp. 331-364. http://dx.doi.org/10.1093/rfs/13.2.331

[36] S. Coleman and R. Cohn, "Small Firms' Use of Financial Leverage: Evidence from the 1993 National Survey of Small Business Finances," Journal of Business and Entrepreneurship, Vol. 12, No. 3, 2000, pp. 87-103.

[37] R. Cressy, “Are Business Start-Ups Debt-Rationed?" Economic Journal, Royal Economic Society, Vol. 106, No. 438, 1996, pp. 1253-1270.

[38] P. Reynolds, "Informal and Early Formal Financial Support in the Business Creation Process: Exploration with PSED II Data Set," Journal of Small Business Management, Vol. 49, No. 1, 2011, pp. 27-54. http://dx.doi.org/10.1111/j.1540-627X.2010.00313.x

[39] G. Guidici and S. Paleari, "The Provision of Finance to Innovation: A Survey Conducted among Italian Technology-Based Small Firms," Small Business Economics, Vol. 14, No. 1, 2000, pp. 37-53. http://dx.doi.org/10.1023/A:1008187416389

[40] T. Bates, "Entrepreneur Human Capital Inputs and Small Business Longevity," The Review of Economics and Sta- 
tistics, Vol. 72, No. 4, 1990, pp. 551-559.

http://dx.doi.org/10.2307/2109594

[41] S. Paul and G. Whittam and J. Wyper, "The Pecking Order Hypothesis: Does It Apply to Start-Up Firms?" Journal of Small Business and Enterprise Development, Vol. 14, No. 1, 2007, pp. 8-21. http://dx.doi.org/10.1108/14626000710727854

[42] H. Fourati and H. Affes, "Financial Constraints, Human and Social Capital, and Risk-Taking Attitude in the Foundation of New Firms," Strategic Change: Briefings in Entrepreneurial Finance, Vol. 20, No. 5-6, 2011, pp. 219-232. 